\title{
Optimation of Layers Thickness Design of Perovskite Solar Cell (PSC) Using GPVDM Simulation
}

\author{
Dita Puspita ${ }^{1, a}$ \\ ${ }^{1}$ Department of Physics, Faculty of Mathematics and Natural Sciences, Universitas Jember, \\ Jalan Kalimantan No. 37 Jember 68121 \\ aummushafiyyah88@gmail.com
}

\begin{abstract}
In this research, perovskite solar cells by configuring ITO/PEDOT:PSS/CH $\mathrm{NH}_{3} \mathrm{Pbl} / \mathrm{ZnO} / \mathrm{Al}$ changed to optimize their performance. Modifications are made by varying the thickness of each layer to increase the ideal thickness with an optimal power conversion efficiency (PCE) value. This research used GPVDM software to study several power conversion efficiency (PCE) parameters of ITO/PEDOT:PSS/ $\mathrm{CH}_{3} \mathrm{NH}_{3} \mathrm{Pbl}_{3} / \mathrm{ZnO} / \mathrm{Al}$ solar cells. The results of the study show that the power conversion efficiency (PCE) can be increased by adjusting the thickness of the coating, in this study the ideal thickness with the highest power conversion efficiency $25.75 \%$ in $1 \times 10^{-8} \mathrm{~m}$ of ITO, $1 \times 10^{-6} \mathrm{~m}$ of PEDOT:PSS, $4 \times 10^{-7} \mathrm{~m}$ of CH3NH3Pbl3, $1 \times 10^{-8} \mathrm{~m}$ of $\mathrm{ZnO}$ and $1 \times 10^{-9} \mathrm{~m}$ of Al.
\end{abstract}

Keywords: PSC, PCE, GPVDM software, layer thickness modification

\section{Introduction}

Solar energy is a reliable alternative energy source because it is abundant and environmentally friendly. In this perspective, developing solar cells is one of the best approaches to convert solar energy into electrical energy based on the photovoltaic effect. Until now, the advancement of solar cell technology is growing so rapidly. For many years, silicon-based solar cells have been used for industrial purposes with efficiencies reaching $30 \%$, especially crystalline silicon-based solar cells [1]. But behind its advantages are high production costs and are difficult for large industries to use. Another alternative is third-generation solar cells. Third-generation solar cells are capable of producing photo-to-electricity conversion devices with high efficiency and much lower production costs. There are several classifications of technologies included in the third generation of solar cell technology, including dye-sensitive solar cells, quantum dot solar cells (QDs), and perovskite-sensitive solar cells [2]. Of the three types of solar cells included in this third-generation solar cell technology, perovskite-based solar cells appear to have a very good opportunity to contribute to large-scale solar energy production based on high PCE and compatibility with scalable processes. However, there are challenges in the perovskite-based solar cell production process, namely long-term stability [3]. Various efforts have been made to maximize the efficiency of perovskite-based solar cells. In research on solar cells based on $\mathrm{CH}_{3} \mathrm{NH}_{3} \mathrm{PbBr}_{3}$ with a high photovoltage of $0.96 \mathrm{~V}$ and the value of the efficiency is 3.8\% [4]. In a study on $\mathrm{CH}_{3} \mathrm{NH}_{3} \mathrm{Pbl}_{3}$ measuring $2-3 \mathrm{~nm}$ and giving an efficiency of $6.54 \%$ [5]. In different studies achieved an astonishing efficiency of $16.2 \%$ [6]. Study on the effect of layer thickness on the power conversion efficiency of $\mathrm{CH}_{3} \mathrm{NH}_{3} \mathrm{Pbl}_{3}$ based planar heterojunction solar cells and the results showed by adjusting layer thickness in our case power conversion efficiency was increased from $9.96 \%$ to $12.9 \%$ [7]. And in a study on the $\mathrm{CH} 3 \mathrm{NH} 3 \mathrm{Pbl} 3$ thickness effect on device efficiency in planar heterojunction perovskite solar cells showed the optimization of the layer thickness yielded devices with efficiencies of up to $11.3 \%$. The results further demonstrate 
that a delicate balance between light absorption and carrier transport is required in these planar heterojunction devices, with the thickest perovskite films producing only very low power conversion efficiencies [8]. Different parameters can increase the PCE of perovskite-based solar cells, one of which is the effect of layer thickness. This research used GPVDM which is a software simulator for photovoltaic, were investigated the effect of layer thickness on PCE in ITO/PEDOT:PSS/ $\mathrm{CH}_{3} \mathrm{NH}_{3} \mathrm{Pbl}_{3} / \mathrm{ZnO} / \mathrm{Al}$ solar cells and obtained the ideal thickness.

\section{Theoretical Background}

General Purpose Photovoltaic Device (GPVDM) is a 1D/2D optoelectronic device model, which can be used to simulate solar cells, LEDs, diodes, FETs, etc. Simulations were carried out using the General Purpose Photovoltaic Device Model (GPVDM). This simulator is based on solving Poisson Equation (1) to obtain voltage $\emptyset$,

$\frac{d}{d x}\left(\epsilon_{0} \epsilon_{r}\right) \cdot \frac{d \emptyset}{d x}=q(n-p)$

where front anode $(x=0)$ dan back cathode $(x=d), \epsilon_{0}$ is the permittivity of free space, $\epsilon_{r}$ is relative permittivity, $q$ is the elementary charge, $n$ and $p$ is free electron and hole population.

Something not less important in solar cells is the offset of band edges of the HOMO and LUMO levels will prove responsible for the improvement of all photovoltaic properties of the organic solar cells. Since a deep $\mathrm{HOMO}$ level is desirable for obtaining high open-circuit voltage $\left(\mathrm{V}_{\mathrm{OC}}\right)$ since the maximum value of the $\mathrm{V}_{\mathrm{OC}}$ is determined by the energy difference between the HOMO (Highest Occupied Molecular Orbital) level of the donor and LUMO (Lowest Unoccupied Molecular Orbital) level of the acceptor.

Drift diffusion equation (momentum conservation equation) for electron:

$J_{n}=q \mu_{e} n \frac{\partial E_{c}}{\partial x}+q D_{n} \frac{\partial n}{\partial x}$

for hole:

$J_{p}=q \mu_{h} n \frac{\partial E_{v}}{\partial x}+q D_{p} \frac{\partial p}{\partial x}$

$E_{c}$ dan $E_{v}$ define the carrier mobility and define $E_{c}=-\chi-\emptyset$ and $E_{v}=\chi-E_{g}$, where $\chi$ is a difference of LUMO mobility and vacuum level and $E_{g}$ is a difference of HOMO and LUMO mobility.

To describe carrier trapping, d-trapping recombination used $\mathrm{SRH}$ recombination model for electron and hole, which assume a steady-state distribution of trapped charge carries in the trap states.

$$
R_{T}=\frac{n p-n_{i}^{2}}{\tau_{P 0}\left[n+n_{i} \exp \left(\frac{E_{t}-E_{i}}{k T}\right)\right]+\tau_{n 0}\left[p+n_{i} \exp \left(\frac{E_{i}-E_{t}}{k T}\right)\right]}
$$


This form of the SRH equation is therefore not suitable for time-domain simulations, where trapping or recombination via trap states dominate charge dynamics. As the charge carriers can not go out of equilibrium [9].

So, to solve the charge density of each trap state explicitly needed to split space up the energy into energy slice and use SRH equations but don't assume steady-state so solved the SRH equation explicitly in the time domain. Each trap state gets its rate equation

$\frac{\partial n_{t}}{\partial t}=r_{e c}-r_{e e}-r_{h c}+r_{h e}$

$r_{e c}$ is the rate at which free electrons get trapped, $r_{e e}$ is the rate at which electrons can escape from the trap back to the free electron population, $r_{h c}$ is the rate at which free holes get trapped and $r_{h e}$ is the rate at which holes escape back to the free hole population. Electron recombination rate $\left(R_{e}\right)$ in equation (2) can be calculated by subtracting the total number of electrons that escape all traps into the carrier free electron population from the total number of electrons captured from the free carrier population into all traps. An analogous procedure is carried out to calculate $R_{h}$ for free holes. More detailed equation resolving and device modeling can be found in more detail in $[10,11,12-16]$.

\section{Materials and Methods}

Figure 1, shows the design of ITO/PEDOT:PSS/CH${ }_{3} \mathrm{NH}_{3} \mathrm{Pbl}_{3} / \mathrm{ZnO} / \mathrm{Al}$ solar cells in this research. Table 1 is shown initial parameters that were carefully picked from practical and theoretical references.

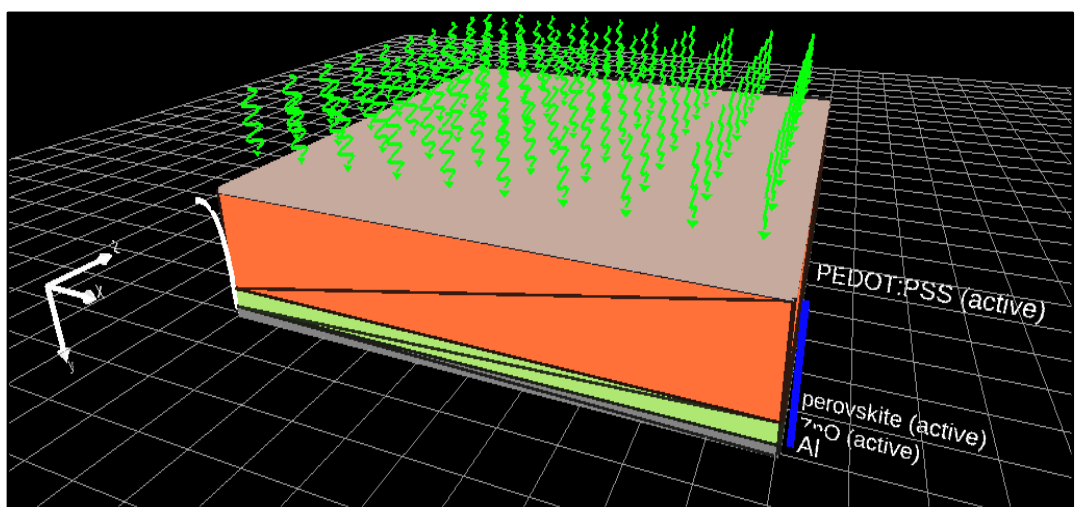

Figure 1. Desain of ITO/PEDOT:PSS/CH $\mathrm{NH}_{3} \mathrm{Pbl} / \mathrm{ZnO} / \mathrm{Al}$ solar cells in this research

Table 1. Simulation Parameters

\begin{tabular}{lcccc}
\hline \multicolumn{1}{c}{ Parameters } & ITO [7] & $\begin{array}{l}\text { PEDOT:PSS } \\
{[12]}\end{array}$ & $\mathbf{C H}_{3} \mathbf{N H}_{3} \mathbf{P b l}_{3}$ [7] & ZnO [13] \\
\hline Layers thickness $(\mathrm{m})$ & $1 \times 10^{-7}$ & $2 \times 10^{-7}$ & $4 \times 10^{-7}$ & $2 \times 10^{-7}$ \\
Electron mobility $\left(\mathrm{m}^{2} / \mathrm{V} . \mathrm{s}\right)$ & $6.86 \times 10^{-7}$ & 0.002 & 0.002 & 0.02 \\
Hole mobility $\left(\mathrm{m}^{2} / \mathrm{V} . \mathrm{s}\right)$ & $3.75 \times 10^{-2}$ & 0.002 & 0.002 & 0.018 \\
Relative permittivity $\varepsilon_{\mathrm{r}}$ & 3 & 3 & 20 & 2250 \\
Eg $(\mathrm{eV})$ & 0 & 1.6 & 2.1 & 3.35 \\
Electron affinity $(\mathrm{eV})$ & 4.7 & 1.6 & 1.6 & 4.3 \\
Donor concentration $\left(\mathrm{m}^{-3}\right)$ & $5 \times 10^{26}$ & $5 \times 10^{23}$ & $5 \times 10^{23}$ & $5 \times 10^{23}$ \\
Acceptor concentration $\left(\mathrm{m}^{-3}\right)$ & $5 \times 10^{26}$ & $5 \times 10^{23}$ & $5 \times 10^{23}$ & $5 \times 10^{2 \zeta}$ \\
\hline
\end{tabular}


This simulation research is based on the study of the effect of different thicknesses on power conversion energy (PCE). Initial thickness given in Table 1 yields power conversion energy $7.2 \%$, fill factors is $55.12 \%$, open circuit voltage is $0.974 \mathrm{~V}$, and short-circuits density of current is $-134 \mathrm{~A} / \mathrm{m}^{2}$.

\section{Results and Discussion}

Optimation of the thickness of every layer was carried out in this research to obtain the ideal thickness of ITO/PEDOT:PSS/CH $\mathrm{NH}_{3} \mathrm{Pbl}_{3} / \mathrm{ZnO} / \mathrm{Al}$ solar cells. Modifications are made one by one on every layer thickness parameter to get the maximum PCE value. Figure 2 is presented the curve of the effect of ITO layers thickness on PCE.

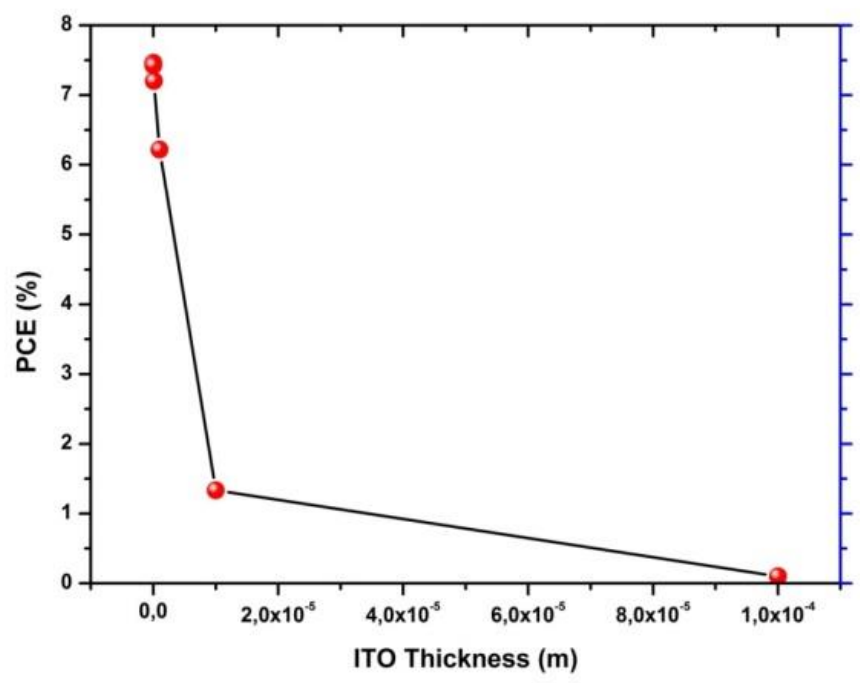

Figure 2. Effect of ITO thickness on PCE

Figure 2 shows the effect of ITO thickness on PCE. The ITO layer thickness of $1 \times 10^{-8} \mathrm{~m}$ has a maximum PCE value of $7.46 \%$, with a fill factor of $55.05 \%$, an open circuit voltage of $0.975 \mathrm{~V}$, and a short-circuit density of current of $-139.04 \mathrm{~A} / \mathrm{m}^{2}$.

So, ITO layer with a thickness $1 \times 10^{-8} \mathrm{~m}$ was set and further modified the PEDOT:PSS layer thickness was to obtain the curve in Figure 3. 


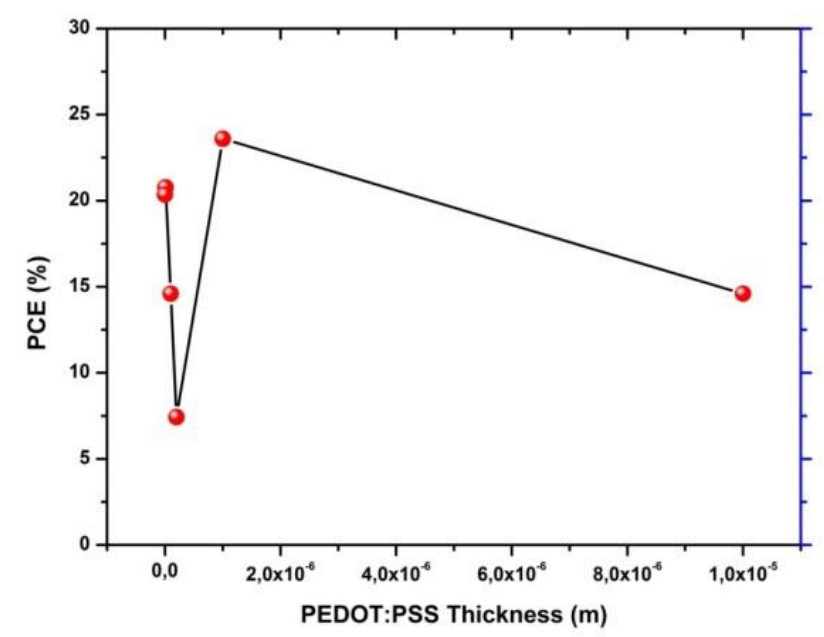

Figure 3. Effect of PEDOT:PSS thickness to PCE

From Figure 3 The Maximum PCE on PEDOT:PSS layer at $1 \times 10^{-6} \mathrm{~m}$ thickness shows $23.59 \%$, with a fill factor is $76.1 \%$, open circuit voltage is $1 \mathrm{~V}$, and a short-circuit density of current of $312.8 \mathrm{~A} / \mathrm{m}^{2}$.

PEDOT:PSS layer thickness was set to $1 \times 10^{-6} \mathrm{~m}$, then $\mathrm{CH}_{3} \mathrm{NH}_{3} \mathrm{Pbl}_{3}$ layer thickness was modified and obtained curve in Figure 4.

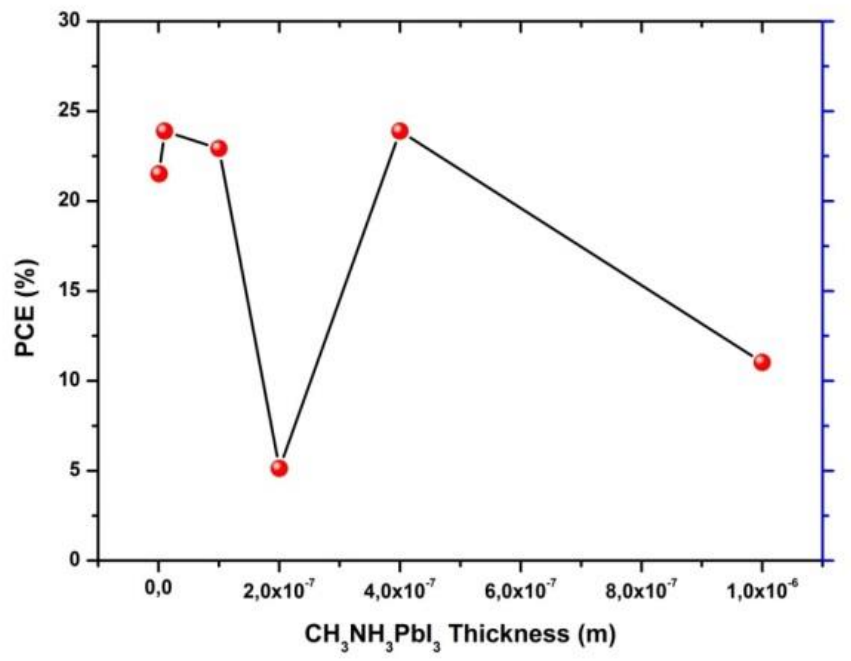

Figure 4. Effect of $\mathrm{CH}_{3} \mathrm{NH}_{3} \mathrm{Pbl}_{3}$ thickness on PCE

In Figure 4 the maximum PCE is $23.89 \%$ in the $\mathrm{CH}_{3} \mathrm{NH}_{3} \mathrm{Pbl}_{3}$ layer thickness of $4 \times 10^{-7} \mathrm{~m}$, with fill factor $76.11 \%$, an open circuit voltage of $1.003 \mathrm{~V}$, and short-circuit density of current of -312.9 $\mathrm{A} / \mathrm{m}^{2}$. 
At $4 \times 10^{-7} \mathrm{~m}$ thickness, the $\mathrm{CH}_{3} \mathrm{NH}_{3} \mathrm{Pbl}_{3}$ was set and modified the $\mathrm{ZnO}$ layer thickness to obtained curve in Figure 5.

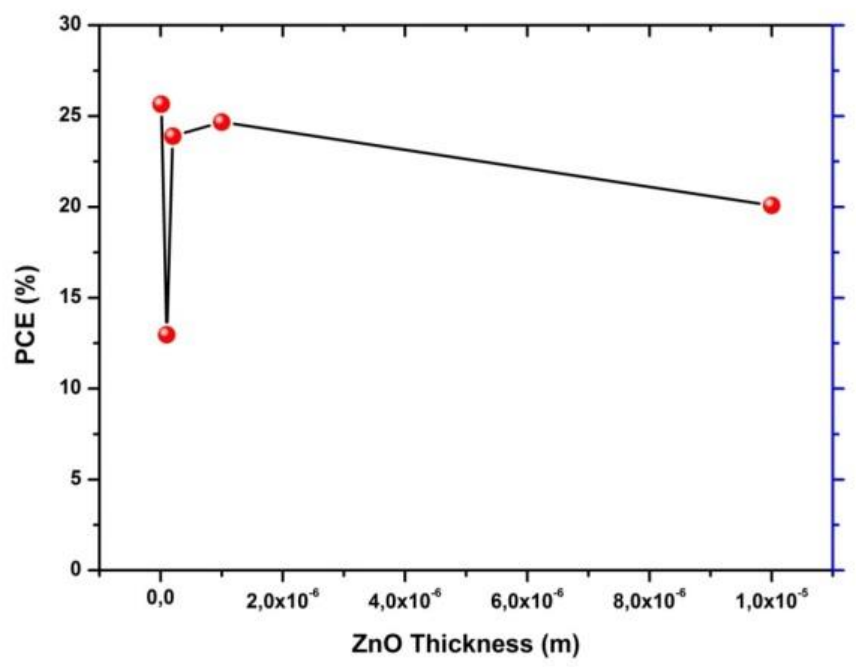

Figure 5. Effect of ZnO thickness on PCE

Figure 5 shows the maximum PCE of $25.65 \%$ at $1 \times 10^{-8} \mathrm{~m} \mathrm{ZnO}$ layer thickness, where fill factor of $87.74 \%$, an open circuit voltage of $1.004 \mathrm{~V}$ and short-circuit density of current of

$-291 \mathrm{~A} / \mathrm{m}^{2}$. The last, after fixed the $\mathrm{ZnO}$ layer thickness at $1 \times 10^{-8} \mathrm{~m}$, the Al layer thickness gets modified to obtain the curve in Figure 6.

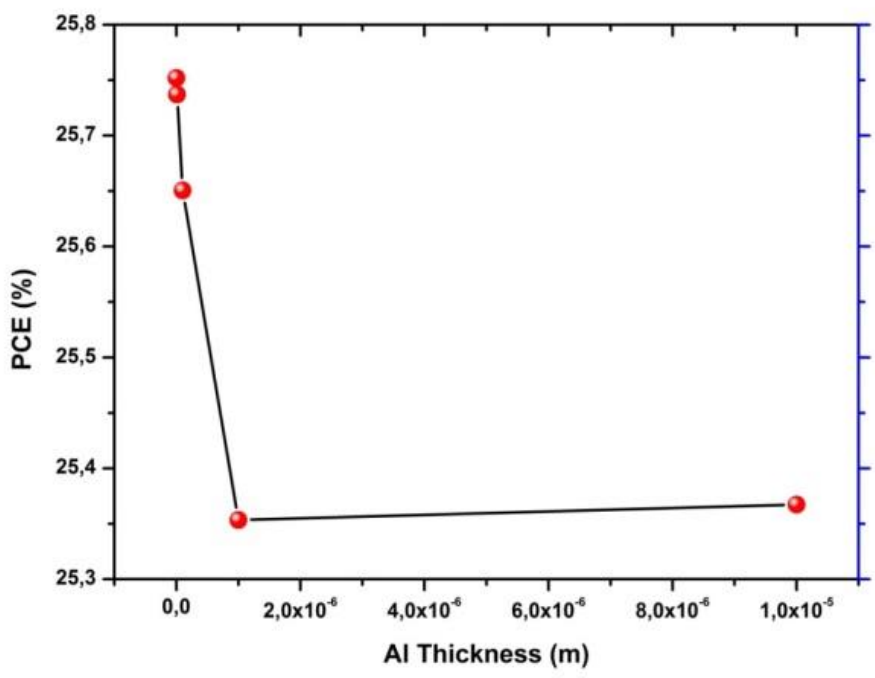

Figure 6. Effect of Al thickness on PCE 
The curve of Figure 6 shows the maximum PCE of $25.75 \%$ is obtained in Al layer thickness of $1 \times 10^{-9} \mathrm{~m}$. The fill factor is $88 \%$, an open circuit voltage is $1.005 \mathrm{~V}$ and the short circuit density of current is $-292.1 \mathrm{~A} / \mathrm{m}^{2}$.

From Figures 2 to 6 could be presented the thickness optimation of every layer give effect to PCE value and the ideal layer thickness of ITO/PEDOT:PSS/CH ${ }_{3} \mathrm{NH}_{3} \mathrm{Pbl}_{3} / \mathrm{ZnO} / \mathrm{Al}$ solar cells design with optimum PCE value: ITO layer thickness of $1 \times 10^{-8} \mathrm{~m}$, PEDOT:PSS layer thickness of $1 \times 10^{-6} \mathrm{~m}, \mathrm{CH}_{3} \mathrm{NH}_{3} \mathrm{Pbl}_{3}$ layer thickness of $4 \times 10^{-7} \mathrm{~m}$, $\mathrm{ZnO}$ layer thickness of $1 \times 10^{-8} \mathrm{~m}$ and $\mathrm{Al}$ layer thickness of $1 \times 10^{-9} \mathrm{~m}$. From the layer thickness optimation, PCE value increased from $0.1 \%$ to $25.75 \%$.

\section{Conclusions}

ITO/PEDOT:PSS $/ \mathrm{CH}_{3} \mathrm{NH}_{3} \mathrm{Pbl}_{3} / \mathrm{ZnO} / \mathrm{Al}$ power conversion efficiency was analyzed using the GPVDM solar cell software simulation. Results show that a good choice of the layer thickness of different materials used in the solar cell increases considerably the PCE ratio. Simulation results show that an improvement at ITO layer thickness of $1 \times 10^{-8} \mathrm{~m}$, PEDOT:PSS layer thickness of $1 \times 10^{-6} \mathrm{~m}, \mathrm{CH}_{3} \mathrm{NH}_{3} \mathrm{Pbl}_{3}$ layer thickness of $4 \times 10^{-7} \mathrm{~m}, \mathrm{ZnO}$ layer thickness of $1 \times 10^{-8} \mathrm{~m}$, and Al layer thickness of $1 \times 10^{-9} \mathrm{~m}$. It has $25.75 \%$ of PCE value. Further PCE enhancements can be optimized by changing layer structure and materials.

\section{References}

[1] National Renewable Energy Laboratory (NREL), 2018, Best Research-Cell Efficiency Chart, executive summary on https://www.nrel.gov/pv/cellefficiency.html accessed on June 5, 2018.

[2] G. Coonibear, 2007, Third Generation Photovoltaics, Materials Today, volume 10 (11), page 42-50.

[3] M. Alfaz, Bagawan and G. Kaveri S, 2017, Perovskite Solar Cells, International Journal of Advance Research in Science and Engineering (IJARSE), ISSN: 2314-8354, volume 6, issue 10.

[4] A. Kojima, K. Teshima, Y. Shirai and T. Miyasaka, 2009, OrganometalHalide Perovskites as Visible-Light Sensitizers for Photovoltaic Cells, Journal of the American Chemical Society, volume 131, no. 17, page 6050-6051.

[5] J.H. Im, C.R. Lee, J.W. Lee, S.W. Park and N.G. Park, 2011, 6.5\% Efficient Perovskite Quantum-Dot-Sensitized Solar Cell, Nanoscale, volume 3, no. 10, page 4088-4093.

[6] M. A. Green, A. Ho-Baillie and H. J. Snaith, 2014, The Emergence of Perovskite Solar Cells, Nature Photonics, volume 8, no. 7, page 506-514.

[7] A. Hima, A. Khechekhouche, I. Kemerchou, N. Lakhdar, B. Benhaoua, F. Rogti, I. Telli and A. Saadoun, 2018, GPVDM Simulation of Layer Thickness Effect on Power Conversion Efficiency of $\mathrm{CH}_{3} \mathrm{NH}_{3} \mathrm{Pbl}_{3}$ Based Planar Heterojunction Solar Cell, International Journal of Energetica (IJECA). ISSN: 543-3717, volume 3, issue 1.

[8] L. Dianyi, G. Mahesh K and K. Timothy L, 2014, Effect of CH3NH3Pb/3 Thickness on Device Efficincy in Planar Heterojunction Perovskite Solar Cells, Journal of Materials Chemistry A: Royal Society of Chemistry.

[9] M. Roderick C. I, 2018, GPVDM User Manual, https://www.gpvdm.com/docs/educators/workbook/workbook.pdf accessed on April 6, 2018. 
[10] R. C. I. MacKenzie, T. Kirchartz, G. F. A. Dibb, and J. Nelson, 2011, Modeling Nongeminate Recombination in P3HT:PCBM Solar Cells, J. Phys. Chem. C, volume 115, no. 19, page 9806-9813.

[11] F. Deschler, D. Riedel, B. Ecker, E. von Hauff, E. Da Como, R.C.I. MacKenzie, 2012, Increasing Organic Solar Cell Efficiency with Polymer Interlayers, Phys. Chem, volume 15, no. 3, page 764-769.

[12] R. C. I. MacKenzie, C. G. Shuttle, M. L. Chabinyc and J. Nelson, 2012, Extracting Microscopic Device Parameters from Transient Photocurrent Measurements of P3HT:PCBM Solar Cells, Advanced Energy Materials, volume 2, no. 6, page 662-669.

[13] S. M. Sze and K. N. Kwok, 2007, Physisc of Semicondctor Device, New Jersey, John Wiley and Sons Inc.

[14] F. Hao et al, 2014, Lead Free Solid State Organic-Inorganic Halide Perovskite Solar Cells, Nature Photonics, volume 8, no. 6, page 489.

[15] T. Minemoto and M. Murata, 2015, Theoretical Analysis on Effect of Band Offsets in Perovskite Solar Cells, Solar Energy Materials and Solar Cells, volume 133, page 8-14.

[16] P. Umari, E. Mosconi and F. De Angelis, 2014, Relativistic GW Calculations on $\mathrm{CH}_{3} \mathrm{NH}_{3} \mathrm{Pbl}_{3}$ and $\mathrm{CH}_{3} \mathrm{NH}_{3} \mathrm{SnI}_{3}$ Perovskites for Solar Cell Applications, Scientific Reports, volume 4, page 4467. 